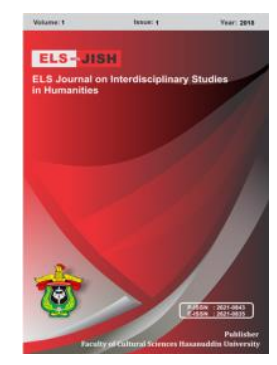

ELS-JISH

ELS Journal on Interdisciplinary Studies on Humanities

Volume 1 Issue 1, 2018

ISSN (print) : 2621-0843

ISSN (online) : 2621-0835

Homepage : http://journal.unhas.ac.id/index.php/jish

\title{
Word-Level Translation Techniques in Medical Terms From English into Indonesian
}

\author{
Yohanis Rongre $^{1 *}$, Noer Jihad Saleh \\ ${ }^{\star} E$-mail of Corresponding Author: yohanesrongre eb@yahoo.co.id
}

\begin{abstract}
The aim of this study was to describe the use of translation techniques and the impact of the use of translation techniques on the accuracy and acceptability of medical terms in book of the Foundation Module: the midwife in the community. The method used in this research was a mixed method design, combining quantitative and qualitative approaches as it to discuss the quantification of the frequency of translation techniques used by the translator to translate medical terms and the impact of translation techniques applied on the accuracy and acceptability of the medical term translations. The source of data in this study is a book entitled Foundation Module: the midwife in the community and its Indonesian translation and 6 informants as well as a rater to assess the quality of medical terms translation. The results of this study showed that translation of medical terms of total 334 data dominated by naturalized borrowing $32.63 \%$, calque $16.77 \%$ and description technique $8.38 \%$. Meanwhile, quality assessment of the accuracy level of the translation showed a highly accurate $80.24 \%$ and assessment of acceptability $86.53 \%$. Mostly the techniques used in translating medical terms give a positive influence for the accuracy and acceptability level of translation because the techniques used delivery the same information from the source language into the target language which is accepted linguistically.
\end{abstract}

Keywords: Technique, Medical Term, Accuracy, Acceptability.

How to cite: Rongre, Y., \& Saleh, N. J. (2018). Word-Level Translation Techniques in Medical Terms From English into Indonesian. ELS-Journal on Interdisciplinary Studies in Humanities, 1(1), 66 - 75.

\section{Introduction}

The development of a new vocabulary in scientific knowledge and medical technology that is so fast every year shows that a large number of new terms are increasing in the dictionary of medical terms. Due to the need to immediately update the knowledge, the health professionals inevitably have to learn directly in the original language of publication and stick to it in daily usage.

As a consequence of the language use in the medical community, there are many trainings that support English proficiency in both formal English and English for medical (English for Specific Purposes). Emalia Iragiliati (2007), stated that The medical specialists were taught the text structure of medical abstract and its content. By doing this it will build the background knowledge. To activate the background knowledge, the medical specialists are taught the vocabulary and grammar that are commonly used in science

\footnotetext{
${ }^{1,2}$ Faculty of Cultural Sciences, Hasanuddin University 
texts. The vocabulary consist of quantifications, formulae, symbols, rhetoric texts: descriptions, analysis, argumentations, etc., technical words, sub-technical words.

In relation to the development of translation in Indonesia, efforts to translate books of science and technology are necessary. Indonesia is a developing country, so translation of science and technology books needs to be done for various reasons. Among the reasons according to Nababan (2012) are as follows: first, as a developing country, Indonesia wants to improve the progress in science and technology by translating scientific text books from foreign languages into Indonesian languages on large scale. Second, most science and technology books are written in many foreign languages, especially English, whereas the readers are mostly difficult to obtain scientific books in the source language.

Book of Foundation Module: the midwife in the community; Education material for teachers of midwifery, and its translation, First Edition by World Health Organization, published by EGC Medical Book Publisher (2001), was translated by Maria A. Wijayarini. It is one contribution to transfer science of medical field through a translation products.

There are two fundamental reasons underlying the researcher in selecting the book as the writing material of this thesis. First Book Foundation module: the midwife in the community; Education material for teachers of midwifery, and its translation is a textbook on medical that provides evidence-based information and applications, based on the collaborative experience of many education centers. This book is presented in the form of text and images aimed at pre-clinic level of midwife students and obstetricians.

Then comes several question such as translator's technique in translating medical term and impact of the translation techniques applied by the translator toward the translation quality of the medical terms of accuracy and acceptability

There are two previous researches that are related to translation strategies for medical term. Both will become reference for future research. First is Nina Rask (2008) conducted the research deals with the difficulties in translating a medical text from English into Swedish. As primary source, she used a British textbook about geriatrics called Nursing Older People which is aimed at university students of nursing. On her analysis shows the translation difficulties have involved terminology and cultural aspects and how those problems were tackled by studying different translation theories. The terminological problems involved choosing the most appropriate term for describing diagnosis, diseases, body organs and symptoms. There was a wide variety of terms from old Graeco-Latin terms to English terms coined in the 1990s. A suitable choice was possible by considering aspects like frequent usage of field specific words and collocations in parallel texts. In short, she focused on the cultural aspects involved cultural references such as differences between Sweden and the UK as for national institutions and organisations. The solution was to find a cultural equivalent or, when this was not possible, explain the term in a footnote. Then this research becomes a reference for researcher to find the translation techniques in medical terms translation. The second is Nuning Yudhi Prasetyani (2009) wrote a thesis 'An Analysis on Transposition and Modulation of sentences In "Fisiologi Kedokteran" Book by Adji Dharma'. This thesis is an analysis on text and its context. The study focus on transposition and modulation forms which are in 'Fisiologi Kedokteran' book. Nuning Yudhi Prasetyani revealed in his research that effect in applying transposition and modulation technique referring to the quality of translation product and to give the alternative translation. The accuracy and readability level are caused by: (1) the use of incomplete sentence, (2) the use of inappropriate device, (3) the use of 
inappropriate diction, (4) the use of ungrammatical phrase structure caused by the translator did not understand about what the author's intend, (5) there are many deletions, both in a part of sentence and in a sentence, (6) the use of wrong preposition, (7) the use of inappropriate changing of passive voice into active voice, but it changes the meaning. This research result also support the theory that a translator must master in source language, target language, text being translated and the most important thing is to understand well on the translation theory. So, this research is very important in supporting recent theories and it is hoped that a translator will understand and apply them in producing a good quality of translation

In addition, researcher also developed a study to find out how high the quality of translation results generated by the translator seen from the accuracy, acceptance. It is this that encourages researchers to do this research by combining the facts in the field, which is analyzing the translation of Foundation module: the midwife in the community; Education material for teachers of midwifery. In this research, writer will focus on the techniques and quality of medical terms translation. The use of translation techniques greatly affects the quality of the translations produced. The forms of translation techniques will be examined to determine the accuracy and acceptance the result of medical terms translation.

\section{Research Method}

\subsection{Research Design}

The design of this research was a mixed method design, combining quantitative and qualitative approaches.

\subsection{Source of Data}

As stated by Sutopo (2002), source of the data in research can be informant, event, place, and document, the researcher uses various sources of data in this research. The data studied in this research is divided into primary and secondary data. The primary data included are: 1) all data included in medical terms and translations in Indonesian, and 2) informant data, ie the results of questionnaires and focus group discussions of the rater on the accuracy and acceptability. Meanwhile, the secondary data in this study is all information related to the book of the Foundation Module: the midwife in the community and its Indonesian translation.

\subsection{Method of Data Collection}

In collecting the data, the researcher applied two methods. The methods were content analysis and questionnaire. Content analysis helped the researcher findings the translation techniques. While the other method, the researcher obtained the data of translation qualities. The informants were given questionnaire about the accuracy and acceptability of the translation. In this method, the informants were required to complete the questionnaire in order to rate the acceptability and accuracy of the translation based on the scales determined by the researcher. According to Nababan et al (2012) scale for scoring accuracy divided into three parts: inaccurate, less accurate and accurate.

\subsection{Method of Data Analysis}

The facets were: (1). Observed the medical terms both written in source language and target language, (2). the collected data were observed and compared between the original messages with the translation version. Then, the researcher asked the informants 
to analyze the quality of the translation in terms of accuracy, and acceptability, (3). counted the percentage of each classification. To find out the percentage of the type of translation techniques, this thesis applied a formula referring to Nawawi's social analysis method (Nawawi 1993), and finally, (4). The researcher drew the conclusion of the results of the analysis.

\section{Findings}

\subsection{Types of Medical Terms}

After exploring the book of Foundation Module: the midwife in the community and its translation and in specializing on medical terms, researchers found 334 medical terms which is divided into words and phrases. The first type is words, according to Kamus Besar bahasa Indonesia (2012), is defined as the smallest unit that can be expressed as a free form, This is due to the frequency of occurrence of the word occupies the first position and then the phrase in the sources language. The researcher found 181 words in the source language (SL) and 144 words in target language (TL). In this type, researcher found four classifications of translation form. First is the word absorbed into Indonesian language (naturalized borrowing) with 109 data of words or 38,93\%, such as cervical (SL) - serviks (TL). Second is a word matching or translated in Indonesian (literal translation) with 21 word data of the term or $7.50 \%$, as example pregnancy $(\mathrm{SL})$ - kehamilan (TL). The third is a word borrowed directly into Indonesian language (pure borrowing) with 19 data of words or $6.79 \%$, for example omnion (SL) -omnion (TL). And the last form of word is translation by paraphrase (Amplification) with 44 data of words or $15.71 \%$, such as vaginitis (SL) - infeksi vagina (TL). The other type of medical term data that has been found is phrases. The phrase in the linguistic dictionary (2008: 66), is a sequence of two or more words arranged in a grammatical construction and acting as a unit in a sentence. The researcher found 153 phrases terms in source language and 190 phrases terms in target language, such as obstructed labour (SL) - persalinan terhambat (TL).

\subsection{Applied Translation Technique}

This research applied translation theory of Molina and Albir (2002), Vinay and Darbelnett (2000) which is the basis for reference to identify data on translation techniques used in medical terms in the book of Foundation Module: the midwife in the community and its translation. There are two translation s techniques found based on the findings of frequency of translation techniques application such as single technique (application of one translation technique), combination technique (application of combination translation techniques in one term). And then the researcher found the application of translation technique in 334 medical terms are divided into two variants, are as follows: 280 data $(83,83 \%)$ translated by 11 single translation techniques and 54 data $(16,17 \%)$ of medical terms translated by using 11 combination of translation techniques. as the table below:

Table 1. The distribution of frequency of single translation techniques

\begin{tabular}{clcc} 
NO & \multicolumn{1}{c}{ Techniques } & $\Sigma$ & $\%$ \\
\hline 1 & $\begin{array}{l}\text { Literal Translation (also known as word-for-word translation by } \\
\text { Larson (1984)). Example: Maternal death (SL) - Kematian ibu (TL) }\end{array}$ & 21 & 7.50 \\
\hline 2 & $\begin{array}{l}\text { Reduction. Ex: Human Immunodeficiency Virus (HIV) (SL) - HIV } \\
(\mathrm{TL})\end{array}$ & 2 & 0.71 \\
\hline 3 & Naturalized Borrowing. Ex: Antibiotic (SL) - Antibiotik (TL) & 109 & 38.93 \\
\hline 4 & Transposition. Ex: Prolonged rupture of membranes (SL) - & 1 & 0.36 \\
\hline
\end{tabular}


ISSN: (E) 2621-0835, (P) 2621-0843

\begin{tabular}{clcc}
\hline \multicolumn{5}{l}{ Ketuban pecah lama (TL) } \\
\hline 5 & Amplification.Ex: Antepartum (SL) - Sebelum kelahiran (TL) & 16 & 5.71 \\
\hline 6 & Modulation. Ex: Tenderness (SL) - Nyeri tekan (TL) & 1 & 0.36 \\
\hline 7 & Particulation. Ex: Specific grafity (SL) - Berat jenis (TL) & 2 & 0.71 \\
\hline 8 & Pure Borrowing. Ex: Uterus (SL) - Uterus (TL) & 19 & 6.79 \\
\hline 9 & Establish Equivalence. Ex: Potency (SL) - Potensi (TL) & 25 & 8.93 \\
\hline 10 & Description. Ex: Humerus (SL) - Tulang lengan atas (TL) & 28 & 10.00 \\
\hline 11 & Calque. Ex: Medical audit (SL) - Audit medis (TL) & 56 & 20.00 \\
\hline & Total & 280 & 100.00 \\
\hline
\end{tabular}

Table 2. The distribution of frequency of combination translation techniques

\begin{tabular}{clcc}
\multicolumn{1}{c}{ Techniques } & $\Sigma$ & $\%$ \\
\hline 1 & $\begin{array}{l}\text { Literal Translation + Naturalized Borrowing. Ex: Atonic } \\
\text { bleeding (SL) - Pendarahan atonic (TL) }\end{array}$ & 20 & 37.04 \\
\hline 2 & $\begin{array}{l}\text { Calque+ amplification + Literal Translation. Ex: Chronic iron } \\
\text { deficiency anemia (SL) - Anemia defisiensi zat besi menahun (TL) }\end{array}$ & 1 & 1.85 \\
\hline 3 & $\begin{array}{l}\text { Pure Borrowing + transposition. Ex: Cervical ostium (SL) - } \\
\text { Ostium serviks (TL) }\end{array}$ & 2 & 3.70 \\
\hline 4 & $\begin{array}{l}\text { Pure Borrowing + Amplification. Ex: Misshapen pelvis (SL) - } \\
\text { Pelvis tidak normal (TL) }\end{array}$ & 1 & 1.85 \\
\hline 5 & $\begin{array}{l}\text { Literal Translation + Amplification. Ex: Unwanted pregnancy } \\
\text { (SL) - Kehamilah yang tidak dinginkan (TL) }\end{array}$ & 2 & 3.70 \\
\hline 6 & $\begin{array}{l}\text { Naturalized Borrowing + Amplification. Ex: Unsafe abortion } \\
\text { (SL) - Aborsi yang tidak aman (TL) }\end{array}$ & 4 & 7.41 \\
\hline 7 & $\begin{array}{l}\text { Naturalized Borrowing + Transposition.Ex: Ischial spines (SL) - } \\
\text { Spina iskadia (TL) }\end{array}$ & 7 & 12.96 \\
\hline 8 & $\begin{array}{l}\text { Literal Translation + Calque. Ex: Deep vein thrombosis (SL) - } \\
\text { Trombosit vena dalam (TL) }\end{array}$ & 5 & 9.26 \\
\hline 9 & $\begin{array}{l}\text { Literal Translation + Pure Borrowing. Ex: Antenatal cara (SL) - } \\
\text { Pelayanan antenatal (TL) }\end{array}$ & 7 & 12.96 \\
\hline 10 & $\begin{array}{l}\text { Naturalized Borrowing + Literal Translation + Transposition. } \\
\text { Ex: Extend the knee (SL) - Ekstensi lutut (TL) }\end{array}$ & 1 & 1.85 \\
\hline 11 & $\begin{array}{l}\text { Literal Translation + Transposition. Ex: Amniotic fluid (SL) - } \\
\text { Cairan amniotic (TL) }\end{array}$ & 4 & 7.41 \\
\hline & \begin{tabular}{l} 
Total \\
\hline
\end{tabular} & 54 & 100.00 \\
\hline
\end{tabular}

\subsection{Translation Quality Assessment}

Technical assessment is done by giving questionnaires to each informant. It is expected that each informant will score according to the parameters. Each of assessment consist of 3 people of reader/midwife. Assessment of translation quality can be measured in two aspects. Accuracy and acceptability of translation.

In the first aspect, there are 3 rates of accuracy such as accurate translation, less accurate translation, and inaccurate. Accurate translation refers to the translation that almost perfect, no distortion meaning between the source language and target language, no mistake the use of the terminology and avoid distortion of meaning (Nababan: 2004, Machali: 2009). Furthermore, that accurate translation refers to the translation that no distortion meaning (Silalahi 2012). There are 268 data $(80.24 \%)$ which are included in 
accurate translation for example, Malnutrition (SL) - Malnutrisi (TL). Then, Less accurate is that most words, terms, phrases, or source text have been translated accurately into the TL. However, there is still distortion of meaning or double meaning of translation or meaning omitted, that disturbing the integrity of the message. There are 57 data $(17.07 \%)$ included in the translation is less accurate as Bulge (SL) translated into mata (TL) by using literal translation techniques which to the reader is less favorable so there is ambiguity and distortion of meaning. And the last part of accuracy aspect is inaccurate translation. Inaccurate is the meaning of words, terms, phrases, or SL texts transferred inaccurately to the TL or deleted (Nababan et al, 2012). The essence of an accuracy assessment is the suitability or accuracy of messages conveyed between SL and TL are both viewed from the aspects of linguistics (grammatical structure), semantics and pragmatic. In Inaccurate translation there are 9 data (2.69\%) with example, tenderness in the SL and translated into nyeri tekan in TL are transferred inaccurately into the target language.

Second aspect is acceptability which also has 3 categories to be acceptable for reader. The first is acceptable translation means that the target text sounds natural and it also precise with the principle of the target language. The researcher finds that the translator produces 289 acceptable translations data (86,53\%). Medical terms are translated by using pure borrowing, naturalized borrowing and literal translation. For example, uterus and sputum are translated by pure borrowing technique and the results are acceptable because the term uterus and sputum is commonly used and familiar to its users/readers. The second category is less acceptable translation which the translation sounds natural; but there are still problems with the dictions or grammar. There are 16 less acceptable translations data $(4.79 \%)$, one of the data is Sagittal suture translated into Sutura sagittal is less acceptable on target language because the translation result in a slight error in the term. Sagittal should be translated into sagittalis. Then the last category is unacceptable translation which the translation sounds unnatural; the words, phrases, clauses, and sentences used are inappropriate with the target language's principles. There are 29 not acceptable translation data (8.68\%). For example, the terms of pelvic assessment translate into pengkajian pelvis is unacceptable because the terms used are unusual and unfamiliar for readers of medical terms (audiences) and the terms do not conform to Indonesian rules. Examples of assessment translated into pengkajian, it is should be translated pemeriksaan and rhesus incompatibility translated into the resus tidak komplit, whereas the incompatibility not refers to complete. It can be conclude that the translation terms above are not acceptable to the medical term reader.

Table 3. Assessment of Translation Quality

\begin{tabular}{|c|c|c|}
\hline Aspects & Accuracy & Acceptability \\
\hline \multirow{3}{*}{ Total } & $927: 334=2,78$ & $928: 334=2,78$ \\
\hline & $2,78 \times 3=8,34$ & $2,78 \times 2=5,56$ \\
\hline & \multicolumn{2}{|c|}{$\begin{array}{c}8,34+5,56=13,9 \\
13,91: 5=2,78\end{array}$} \\
\hline
\end{tabular}




\section{Discussion}

After going through several research processes and discovering and collecting the data obtained in the above research findings, this section will cover some of the discussions that will cover more details on translation techniques, the impacts of translation techniques usage towards translation quality of medical terms in Foundation Module: the midwife in the community book. The following are the results of the analysis obtained from several research findings above, namely:

First is translation techniques of medical terms in Foundation Module: the midwife in the community book there are 23 translation techniques has been used, 11 of single techniques that consists of Literal translation, reduction, naturalized borrowing, transposition, amplification, modulation, particularization, pure borrowing, establish equivalence, description, calque and 12 of combination techniques that consists of literal translation + naturalized borrowing, calque+ amplification + literal translation, pure borrowing + transposition, pure borrowing + amplification, literal translation + amplification, amplification + naturalized borrowing, naturalized borrowing + amplification, naturalized borrowing + transposition, literal translation + calque, literal translation + pure borrowing, naturalized borrowing + literal translation + transposition, literal translation + transposition. The existence of variations in the frequency of translation techniques is due to the characteristics of the translation technique itself. The word-level translation technique is the way used to translate from word or phrase from SL into TL. Its application is at the word or phrase level. Judging from the level of application, it appears that the application of translation techniques more than one translation technique is possible. This technique variant is an implication of the power of the translator. In translating a text, the translator has the power to choose the means to be used because translation techniques can be free or compulsory. The technical findings in this study represent the effect of the choices taken by a medical textbook translator entitled Foundation Module: the midwife in the community. These techniques include 334 data translated by a single technique, and 54 data are translated with a combination technique. Of the 334 data, a single technique dominates as many as 280 and only 54 data are combination techniques. From 334 medical terms data, the translation technique used are literal translation 21 data (6.29\%), reduction 2 data $(0.60 \%)$, naturalized borrowing109 data $(32.63 \%)$, transposition 1 data $(0.30 \%)$, amplification 16 data $(4.79 \%)$, modulation 1 data $(0.30 \%)$, particularization 2 data $(0.60 \%)$, pure borrowing 19 data $(5.69 \%)$, establish equivalence 25 data $(7.49 \%)$, description 28 data (8.38\%), calque 56 data (16.77\%), literal translation + naturalized borrowing 20 data $(5.99 \%)$, calque + amplification 1 data $(0.30 \%)$, pure borrowing + transposition 2 data $(0.60 \%)$, pure borrowing + amplification 1 data $(0.30 \%)$, amplification + naturalized borrowing 2 data $(0.60 \%)$, naturalized borrowing + amplification 4 data $(1.20 \%)$, naturalized borrowing + transposition 7 data $(2.10 \%)$ literal translation + calque5 data (1.50), literal translation + pure borrowing 7 data $(2.10 \%)$, naturalized borrowing + literal translation + transposition 1 data $(0.30 \%)$, and literal translation + transposition 4 data $(1.20 \%)$.

The second is the quality of translation of medical terms in Foundation Module with 213 study data: the midwives in the community book tend to have good qualities with the total score 2.78 and can be seen in the final result, accurate translation dominates this research, rather than the less accurate or inaccurate translation. As well as acceptability aspect, the study data were identified predominantly on acceptable translations. Percentage of each aspect of quality-accurate, acceptable, easy to understand-for good 
translation results tend to be dominant, such as accurate $86.5 \%$, acceptable $81.7 \%$, seen from the presentation of the findings, it can be concluded that the application of 11 translation techniques have a good impact on the quality of medical terms translation in the book of Foundation Module: the midwife in the community. Based on the frequency of use of translation techniques, naturalized borrowing techniques and calque techniques predominate in this study. Both of these techniques tend to give a positive value on the quality of the translation. Nevertheless, there are also findings of naturalized borrowing techniques with low accuracy. In insignificant amounts, naturalized borrowing with low accuracy is found in incorrect medical terms. Accurate translation is affected by the correspondence between the source language and the target language. Lack of accuracy is influenced by some unassigned messages. While the inaccuracies are influenced by the difference in meaning between the source language and the target language, so the intent of the term becomes inconsistent with the actual meaning. Acceptable translations are identified with adjustments to cultural rules of the target language. Unacceptable data is caused by mistake in translating medical terms that use different languages in its target language and not in accordance with the rules of the target language. Finally, unacceptability is influenced by grammatical errors in the target language. In the level of readability is identified by the level of convenience of a data to be understood. Less readability is being influenced by the use of foreign terms that are not understood and should be read over and over again, the less readability is the inaccurate and unacceptable translation. The discussion on the impact of the application of translation techniques on translation quality is divided into two sub-chapters, namely the impact on the level of accuracy of the translation and the level of acceptability. In accurate translation of 268 data (80.24\%) resulted from the application of single and combination variants. Single variant application of naturalized borrowing technique, dominantly resulting accurate translation, followed by calque technique, description technique, establish equivalence technique, literal translation technique, pure borrowing technique, amplification technique and followed by combination variant such as literal translation + naturalized borrowing, literal translation + pure borrowing produce accurate translation as well. Less accurate data there are 57 data (17.07\%) consisting of 57 translation techniques namely, literal translation, naturalized borrowing, transposition, amplification, particularization, pure borrowing, establish equivalence, description, calque, literal translation + naturalized borrowing, calque+ amplification + literal translation, pure borrowing + amplification, literal translation + amplification, amplification + naturalized borrowing, naturalized borrowing + transposition, literal translation + calque, naturalized borrowing + literal translation + transposition and literal translation + transposition techniques. Out of overall data, only 9 data $(2,69 \%)$ of 334 total data available. the inaccurate translation techniques such as amplification techniques, naturalized borrowing, modulation, pure borrowing, calque, literal translation + naturalized borrowing, amplification + naturalized borrowing, naturalized borrowing + transposition and literal translation + calque. While in Acceptable translation identified 289 data (86.24\%). The translation is derived from the application of single variant and combination variant technique. The naturalized borrowing technique dominantly yields a grateful translation because this technique is the most widely used in translating these medical terms. But that does not mean that there are no less acceptable terms for this naturalized borrowing technique, there remains only a small part and then followed by all single variant techniques and combination variant of translation techniques, so the whole technique is acceptable. The Less acceptable translation there are 16 data (4.79\%) consists of 7 
techniques i.e: calque, naturalized borrowing, amplification, pure borrowing, literal translation + naturalized borrowing, literal translation + calque, and literal translation + transposition. Unacceptable translation found 29 data $(8.68 \%)$. This translation, resulting from the application of naturalized borrowing, pure borrowing, literal translation, establish equivalence, description, calque, literal translation + naturalized borrowing, amplification + naturalized borrowing, literal translation + pure borrowing, and naturalized borrowing + literal translation + transposition.

\section{Conclusion}

Based on the result of the analysis, the word-level translation strategy in medical terms from English into Indonesia that has been used by midwife community summed up as follow; There are 334 medical terminology data contained in the texts in the Safe Motherhood book which consists of 22 various translation techniques used. The dominant technique used in translating medical terms in the book of Safe Motherhood i.e naturalized borrowing technique as much as 109 data (32.63\%) of the total data and techniques calque 56 data $(16.77 \%)$ of the overall data. Other techniques that are also used are the technique of description of 28 data (8.38\%), establish equivalence 25 data $(7.49 \%)$, literal translation 21 data (6.29\%), pure borrowing 19 data (5.69\%), amplification 16 data (4.79\%) and combination technique of literal translation + naturalized borrowing 20 data $(5,99)$. The second is translation quality of medical terms in the Safe Motherhood book proves to be quite good. It is indicated by accuracy, acceptability with the final result 2.78 . The presentation of the translation is accurate, acceptable and readable, is very high. However, some data, in small quantities, is lacking in quality. This needs to be a concern for translators especially in collaboration with the medical personnel. And the last is the four of the most frequent techniques which influence the quality of the translation are naturalized borrowing, calque, description and establish equivalence. Moreover, the translation quality is categorized good as the score of accuracy is $80.24 \%$ and acceptability is $\mathbf{8 6 . 5 3 \%}$. Meanwhile, inaccuracies often arise from the four techniques above, this is due to the transfer of source language to the target language has a shift in meaning and grammatical errors. As a result, the information provided by the translator is not conveyed in the translation result. The researcher suggests that in translating translator should be a master in the field of source language and target language especially the concept, vocabulary, and terminology because mastery in the source language and the target language affect the quality of the translation results. Especially in translating medical texts, contrastive analysis will be very useful in finding the most way to translate each medical text. A translator should understand the source language text in depth, appropriate in choosing the equivalent word and the description accordance with the target language. In addition, Translators need to know the audiences of the translation (target reader) so that, it can be used as one of the considerations in translation process. Borrowing techniques are preferred to maintain accuracy and other techniques such as calque and descriptions to maintain the level of acceptability and readability. Specific to foreign equivalents in Indonesian, it is recommended for translators to refer to the glossary of the foreign-Indonesian term published by Balai Pustaka in 2008. 


\section{References}

Departemen Pendidikan Nasional. (2008). Glosarium istilah Asing-Indonesia. Balai Pustaka

Departemen Pendidikan Nasional. (2012). Kamus Besar Bahasa Indonesia: Pusat Bahasa Edisi Keempat. Jakarta: PT Gramedia

Larson Mildred, L. (1984). Meaning Based Translation: A Guide to Cross-Language Equivalence. New York: Univ. Press.

Machali, R. (2000). Pedoman bagi penerjemah. Jakarta: Grasindo.

Molina, Lucia dan Albir, Amparo Hurtado. (2002). Translation Techniques Revisited: A Dynamic and Functionalist Approach. Meta Journal des Tranducteur/ Meta: Translators' Journal (XLL VII) No.4, hal. 498- 512.

Nababan, M.R. (2004). Kecenderungan Baru dalam Studi Penerjemahan. Makalah Disajikan dalam Semiloka Penerjemahan yang diselenggarakan oleh Universitas Negeri Jogyakarta pada tanggal 23 Juli 2004.

Nababan, Nuraeni \& Sumardiono. (2012). Pengembangan Model Penilaian Terjemahan. Kajian Linguistik dan Sastra, Vol.24, No.I, Juni2012:39-57

Nawawi, Hadari. (1993). Metode Penelitian Sosial. Yogyakarta: Gajah Mada University Press.

Prasetyani, Nuning Yudhi. (2009). An Analysis on Transposition and Modulation of Sentences in "Fisiologi Kedokteran" Book By Adji Dharma (Thesis). Surakarta..University of Sebelas Maret Surakarta.

Rask, Nina. (2008). Analysis of a Medical Translation: Terminology and cultural aspects (Thesis).Sweden. Linnaeus University.

Silalahi, Roswita. (2000). Padanan Verba Bahasa Inggris Dalam Bahasa Indonesia (Sebuah Studi Kasus Penerjemahan)". Tesis.Medan .Universitas Sumatra Utara.

Sukarni, Emalia Iragiliati. 2007. English for medical purposes, Indonesian for medical purposes, and its pragmatics use. Malang: Bayumedia

Sutopo, H.B. (2002). Metodologi Penelitian Kualitatif: Dasar Teori dan Terapannya dalam

Vinay, Jean-Paul and Jean Darbelnett. 2000. A Methodology for Translation. London and New York: Rouledge.

WHO.2001.Safe Motherhood, Modul Dasasr: Bidan di Masyarakat-Materi Pendidikan Kebidanan.Jakarta:EGC

World Health Organization.(1996). Safe Motherhood,Foundation Modul; the midwife in community-education material for teacher of midwifery. World Health Organization 